\title{
Proto-CSR Before the Industrial Revolution: Institutional Experimentation by Medieval Miners' Guilds
}

\author{
Stefan Hielscher ${ }^{1}$ (1) $\cdot$ Bryan W. Husted ${ }^{2}$
}

Received: 5 October 2018 / Accepted: 15 October 2019 / Published online: 7 November 2019

(c) The Author(s) 2019

\begin{abstract}
In this paper, we argue that antecedents of modern corporate social responsibility (CSR) prior to the Industrial Revolution can be referred to as "proto-CSR" to describe a practice that influenced modern CSR, but which is different from its modern counterparts in form and structure. We develop our argument with the history of miners' guilds in medieval Germanyreligious fraternities and secular mutual aid societies. Based on historical data collected by historians and archeologists, we reconstruct a long-term process of pragmatic experimentation with institutions of mutual aid that address social problems in the early mining industry, and thus before the rise of the modern state and the capitalist firm. Co-shaped by economic and political actors, these institutions of mutual aid have influenced the social responsibility programs of early industrialists, modern social welfare legislation, and contemporary CSR. We conjecture that other elements of proto-CSR might have evolved according to similar trajectories.
\end{abstract}

Keywords History of CSR practice $\cdot$ Proto-CSR · Miners' guild

\section{Introduction}

Recent years have witnessed a surging academic interest in the history of corporate social responsibility (CSR) thought and practice (Carroll et al. 2012; Ciulla 2011). Some scholars have studied how companies can be held responsible for some practices in history, developing a set of criteria for an evaluation of past harmdoing and discussing consequences for the legitimacy of current corporate practices (SchrempfStirling et al. 2016). Others have focused on the design of the antecedents of modern CSR in various historical periods, including the 1800s and 1900s (Djelic and Etchanchu 2017; Etchanchu and Djelic 2018; Husted 2015; Carroll et al. 2012) and the 1600s and 1700s (Pettigrew and Smith

Stefan Hielscher

S.Hielscher@bath.ac.uk

Bryan W. Husted

bhusted@itesm.mx

1 School of Management, Centre for Business, Organisations and Society (CBOS), University of Bath, Claverton Down Rd, Bath BA2 7AY, UK

2 EGADE Business School, Tecnológico de Monterrey, Eugenio Garza Lagüera \& Rufino Tamayo, Valle Oriente, 66269 San Pedro Garza García, NL, Mexico
2017). This new literature has provided guidance for how to legitimately respond to past harmdoing (Schrempf-Stirling et al. 2016). Also, it has prompted thinking about the history of CSR as a social laboratory for learning (Husted 2015) or as an ideological response to the economic and political challenges of the zeitgeist (Djelic and Etchanchu 2017).

However, despite many important insights generated, current scholarship fails to examine the antecedents of CSR as a long-standing path of pragmatic experimentation (Wicks and Freeman 1998) with institutional solutions to social and environmental problems. So far, with only a few exceptions (Husted 2015; Pettigrew and Smith 2017), the literature has predominantly focused on the time of the Industrial Revolution in the nineteenth and twentieth century and, geographically, on the experience in the UK and the US. Located in societies with a clear separation between the economy and politics (cf. Carroll et al. 2012; Husted 2015), these studies ignore earlier periods before the modern era-and thus the possibility that the antecedents of CSR might have emerged from a more fluid institutional environment co-shaped by both economic and political actors. All this suggests that current scholarship fails to capture the rich amalgam of institutional experiences that has influenced modern CSR. This failure means that modern CSR scholarship might be missing opportunities 
for learning how to respond to contemporary challenges (Husted 2015).

The purpose of this paper is to argue that historical antecedents of CSR in periods prior to the Industrial Revolution can be understood as a process of pragmatic experimentation (Wicks and Freeman 1998) with institutions that address societal and environmental challenges. This process involves activities and programs co-shaped by private, economic actors and political authorities that search for institutional innovations for disruptive change and their ensuing challenges. We use the term "protoCSR" to describe these practices.

We show that mutual aid in the medieval mining communities is one such element of proto-CSR. We present a chronological narrative of social policies pursued by miners' guilds in Germany-Goslar (Harz, Lower Saxony), Schwaz (Alps, Tyrol) and elsewhere-reaching from medieval to early modern times. First, in the thirteenth century, self-employed mine-leasing entrepreneurs in Goslar established organizations and institutions of mutual aid to address the social challenges accruing from the production-related grievances of pre-industrial mining. Second, when deemed helpful but fragile, these innovative social policies were supported and gradually formalized by political authorities, sometimes ecclesiastical and sometimes secular, depending on variations in the political and cultural context. Third, we show that these social policies formed a pre-industrial scheme of social security that was constantly developed, changed, improved and applied in new contexts-such as when Goslarian miners migrated to Schwaz following the early fifteenth-century Tyrolian silver rush. Fourth, we show that the path of institutional innovation has influenced the social responsibility programs of leading industrialists and social welfare legislation in nineteenth century, in Germany (McCreary 1968), then in England (Hay 1977; Morgan 1996) and eventually in many other industrialized societies.

Against this backdrop, we hypothesize that both historical and contemporary CSR practices might have evolved from a similar kind of experimentation. We conjecture that business firms start experimenting with institutions to address production-related social and environmental challenges until, at some point, a majority might use the tried-and-tested instruments so broadly that regional and national governments find it easy to apply them universally. At this point, legislation will be met with less resistance since most firms find it easy-and in their interest - to adapt the already well-established practices to the statutory requirements embedded in law. In this sense, the process of co-evolution - the back and forth between businesses and political authorities-might be one long-term mechanism that holds important lessons for what drives and prevents the transition from explicit CSR to implicit CSR (Matten and Moon 2008).
We develop our argument in five steps. In "Theorizing Historical Social Policies and CSR", we summarize current attempts to shed light on the history of CSR practice. "Research Design and Data" outlines our research design and data. "The History of Medieval Mutual Aid Societies in Germany" presents the history of Goslar's medieval miners' guilds and their social programs. Here, we also compare the Goslar experience to the miners' social institutions in medieval Schwaz and elsewhere, and interpret the process as pragmatic experimentation with social institutions to address political-economic crises. In "Implications: Theorizing "Proto-CSR" before the Industrial Revolution", we reconstruct the logic of the German medieval mutual aid societies as proto-CSR. We conclude by discussing further implications for future scholarship.

\section{Theorizing Historical Social Policies and CSR}

While there has been much historical interest in management studies during the last 15 years-described as the "historic turn" by management historians (Clark and Rowlinson 2004) - , scholarship in the history of CSR is of rather recent origin (Cuilla 2011). The general thrust of this emerging literature is to understand CSR as a historical phenomenon and to draw conclusions-either normative or practicalfrom past events for present-day challenges. Historic CSR (Schrempf-Stirling et al. 2016) as well as the history of CSR practice (Carroll et al. 2012; Husted 2015; Pettigrew and Smith 2017) have both received some noteworthy attention in the literature (Parker 2014; Hielscher 2011; Pies et al. 2009) and in major conferences in the field, with wellattended symposia and workshops at the annual meetings of the Academy of Management, International Association for Business and Society, and the Society for Business Ethics, among others. Still, however, these efforts are the tender shoots of a growing plant, the state of which prompts leading scholars in business and society to argue that the field has "suffered from an ahistorical perspective that reinvents the wheel with every new article" (Crane et al. 2015, p. 431).

The emerging scholarship shows two major research foci. First, scholars acknowledge that historical actions, policies or programs of companies can become a moral problem for the present-day operations of companies, for example, when certain practices are judged differently today than when these events took place in the past. Second, and the one which concerns us in this paper, some scholars are interested in the origins of CSR as presented in the historical record of business practices (for an early example, cf. McCreary 1968). In this literature, scholars argue that history can teach important lessons for how firms have responded to unique challenges in the past, e.g. to the sweeping social change that came with the industrialization (cf. Husted 2015). In 
this sense, the history of CSR practice is a "fervid laboratory of social innovation" that "provides a source for possible solutions, paths to be avoided, and fodder for future research," i.e., valuable knowledge potentially relevant for today's challenges (Husted 2015, pp. 137-138). In this spirit, scholars have looked into the history of the nineteenth-century industrial pioneers in Britain (Parker 2014; Ashworth 1951; Pollard 1964) and Germany (McCreary 1968), and the social policies of the British trading companies of the eighteenth and seventeenth centuries (Pettigrew and Brock 2017; Wagner 2017).

Other scholars suggest that the history of CSR is a response of business firms to the "ideological frames" that have shaped the business and society relationships of particular historical episodes (Djelic and Etchanchu 2017, p. 1). Comparing nineteenth-century industrial paternalism and twentieth-century managerial trusteeship with modern CSR, Djelic and Etchanchu (2017, p. 1) argue that globalization "is not the driver of the political role of the firm, but a moderating phenomenon contributing significantly to the dynamics of this shift."

There can be no doubt that the intellectual frames, ideas, and worldviews-in short: the "semantics" (Luhmann 1980; Pies et al. 2009)—shape how individual and collective actors perceive and interpret the world around them and their interactions in it. However, it is equally true that there is a continuity and structural similarity of certain responses to societal challenges_-Luhmann's (1980) "social structureat times when semantics do vary a great deal. For example, we know that a cornerstone of today's CSR activities-the provision of health-related services such as occupational security, health care, and old-age insurance-was developed and refined by the industrial patriarchs in the Prussian Rhine and Ruhr valleys, one of Germany's industrial hubs during the nineteenth-century industrialization (Kastl and Moore 2010; McCreary 1968). From Germany, such corporate programs then found their way to England (Hay 1977; Morgan, 1996), later to the United States and then many other countries. However, McCreary (1968) tells us that the basic structures of these social security and health insurance programs were not invented by the industrial patriarchs but by earlier antecedent practices in mining reaching back to the Middle Ages.

Despite the many skillful analyses, scholarship into the history of CSR practice fails to examine these antecedents of CSR as a long-standing path of pragmatic experimentation (Wicks and Freeman 1998) with institutional solutions to social problems. So far, most research has focused on the Industrial Revolution in the nineteenth and twentieth century (cf., Carroll et al. 2012; Husted 2015) and on the start of the modern era in the eighteenth or seventeenth centuries (cf., Pettigrew and Smith 2017). Earlier cases are seldom mentioned (McCreary 1968), and not analyzed in more detail.
Most cases are geographically located in the UK or the US (Husted 2015). At these times and places, however, CSR is situated in societies with a clear separation between the economy and politics. Studies thus ignore that the antecedents of CSR might have emerged from earlier, pre-modern eras, when the institutional environment was much more fluid-co-shaped by both economic and political actors as economic history tells us (North et al. 2009). As a result, CSR practices have looked very different from their more recent counterparts.

\section{Research Design and Data}

To understand the pre-modern antecedents of CSR, we studied social practices of businesses that have influenced one aspect of modern CSR programs: social policies for employees and local communities. In doing so, we take up McCreary's (1968) idea and studied the origins and the development of social policies in the German miners' guilds and communities of Goslar (Harz, Lower Saxony) and Schwaz (Alps, Tyrol) from medieval to (early) modern times. Together with the Ore Mountains (Saxony and Bohemia), the Harz region and the Tyrolian Alps were the major centers of medieval mining, where mining methods and institutions were most advanced and refined (Lynch 2002). In this study, where we present a chronological narrative of mutual aid societies in medieval mining, we concentrate on the last two, because research has traced the first initiative of professional social insurance to Goslar, and historical records are solid for Schwaz but poorer for the mutual aid societies in Freiberg (Ore Mountains) (Bingener 2012).

Our chronology uses secondary data as accumulated by historical and archeological research. Since the eighteenth century, the data have been collected and intensively debated by a specialized literature on mining history and published in edited volumes and anthologies. Here, we focus on the latest research, including, e.g., Bartels and Slotta (2012) for the economic and legal background of medieval mining in Central Europe and Bartels et al. (2007) for medieval mining in the Harz region. A recent comprehensive history of Germany's miners' guilds and social insurance is provided in Bartels (2012). Our historical narrative is largely based on the studies collected there, in particular, the individual and collective work of Christoph Bartels, Michael Fessner, Lothar Klappauf and Friedrich A. Linke, which is considered the state of the art of Germany's mining history in the Early and High Middle Ages. Further insights also draw on personal correspondence during a 3-h interview with Christoph Bartels in June 2017. To ensure further validity and objectivity (Stutz and Sachs 2018), we have complemented this information with other secondary data collected by other researchers (Kraschewski 2012; Stöllner 2012). 
Investigating the origins of mutual care in Germany's mining industry leads us into distant periods of history for which, in general, only little data are available. Of course, this is one reason why we use a chronological narrative ${ }^{1}$, not a case study method. For example, historical research simply does not know where the first hospital for miners was built in Goslar, Germany, and little is known about how the institutions of mutual aid were applied there and organized in detail. However, there is more evidence about the miners' hospital in Schwaz (Tyrol) built in the early fifteenth century, and likely modeled after its predecessor in Goslar, whose basic elements and organizing principles survived until the 1770s. Often, as in this case, historians and archeologists then resort to comparative clues, logical conclusions and suggestive evidence. We follow this approach in good faith that this is good practice in all sciences wherever data are only scarcely available, and that potential misinterpretations will be identified and corrected by future academic refutations (cf. Baumol 1990).

\section{The History of Medieval Mutual Aid Societies in Germany}

In this section, we first ("The History of Mutual Aid Societies in Goslar (Harz)") document the history of mutual aid societies in the mining industry in Goslar (Harz) between 1200 and 1552 C.E. We then interpret this history as pragmatic experimentation with institutional solutions to disruptive political-economic change ("The Religious Fraternities of Miners in Goslar (1200-1527)"). In so doing, we also incorporate the evidence from other mining districts, including Schwaz (Tyrol), and show that Goslar's experience was no outlier but a model for handling social challenges in medieval mining and metallurgy.

\section{The History of Mutual Aid Societies in Goslar (Harz)}

Historical research suggests that the first religious organization of mutual care among miners was founded in Goslar in the early 1200s or before (Bingener 2012). During this early period of economic growth, flourishing European commerce and trade revitalized mining operations and metallurgy, also in Goslar and the Harz region (Bartels et al. 2007, pp. 77-78). Earlier, after the Carolingian conquests, a permanent settlement of full-time miners, the mining community,

\footnotetext{
${ }^{1}$ Note that our approach is distinct from a typical narrative approach to qualitative research. For Czarniawska (2004), for example, a narrative is a postmodern method, which aims to unveil gender and power relations embedded in the use of language. In our case, we resort to a chronological narrative only because the available data prevents an in-depth case study.
}

was established at the foot of the Rammelsberg mountain near Goslar ("Bergdorf") (Bartels and Klappauf 2012, p. 140). ${ }^{2}$ At this time, pit-owning miners and entrepreneurs operated the mines, not dependent mine workers (Bartels and Slotta 2012; Bartels et al. 2007; Bingener 2012; Bingener et al. 2012).

\section{The Religious Fraternities of Miners in Goslar (1200-1527)}

The religious "Fraternity of Miners of St. Johannis in Goslar" (Bingener 2012, pp. 14-17) is the first organization for mutual care and social insurance documented in history. A charter of Bishop Johann of Hildesheim confirmed the fraternity in 1260 , but it probably came into existence much earlier. The charter affords the privilege of the bishop's personal protection and states that the brotherhood, "in the spirit of God's love, serves the poor and the needy which, through the work in the aforementioned mountain [the Rammelsberg], are haunted by bodily afflictions and hardship." 3 The charter documents its explicit social purpose, which reflects the need to address the miner's working conditions in the mountain and their health consequences. These included injury and fatality caused by rock fall (the Rammelsberg records document a major mine disaster in 1360 with over a hundred casualties), chronic rheumatism stemming from humidity and coldness, and a reduced life expectancy through smoke and sulfur gases, which were emitted from the fires used to exploit the ores (Bingener 2012, pp. 26-27).

The first fraternity of miners in Goslar shows three essential elements (Lauf 2004; Bingener 2012). First, the Fraternity of St. Johannis provided aid to injured, disabled and elderly brothers and their surviving dependents, including widows and children. Support was granted either in the form of alms (paid in money or in kind) to be repaid upon recovery or, in severe cases, hospital care provided by the fraternity's hospital, a small house adjacent to the St. Johannis church. Later, in the fifteenth century, aid also paid for doctors' bills (Lauf 2004, pp. 124-125; Bingener 2012, pp. 18-19). Like all other charity provided by the fraternity, hospital care also served a religious purpose; providing shelter and food was as important as access to the sacraments of the Church to forgive sins. ${ }^{4}$

\footnotetext{
${ }^{2}$ The miners' origins remain in the dark. Only folk legends provide some clues. In Goslar, the old miners' quarter is still called "Frankendorf" (Franconian village), and a folk legend gives an account of "Gundel-Karl", a Franconian miner who allegedly came to Goslar from today's France (Bartels and Klappauf 2012, pp. 127-128).

3 Source: Bishop Johann's 1260 charter, reprinted in Bartels and Klappauf (2012, pp. 176-177). Translation by the authors.

${ }^{4}$ In the medieval worldview, curing the sick was seen to be the responsibility of God, and healing was God's decision. A place close to the church was thus crucial to provide the needy with plentiful
} 
Second, the fraternity provided these social services as mutual aid; fellow miners supported their brothers in need. The brotherhood used donations, endowments and (endowed) rents to fund these activities. Funding is one reason why the 1260 charter grants the fraternity the privilege of a 40-day indulgence package ("Ablass") for donations and endowments made to the benefit of the church of St. Johannis and the fraternity's hospital. Also, historians believe that the fraternity of 1260 had introduced admission fees and membership contributions. There is no hard evidence for proof, but similar financing schemes of most other fraternities in Goslar at the same time provide suggestive clues. In 1409 , a document explicitly speaks of a weekly contribution (a so-called "solidus") to the fraternity's fund (Lauf 2004, p. 126; Bingener 2012, p. 23).

Third, the fraternity was a self-governed religious organization under the supervision (or "protection") of the local bishop. The charter of 1260 counts montani (the miners) as members, but not the silvani (the smelters); it is thus probable that the fraternity only included miners as brothers. These members elected a self-governing body of elders who were accountable to all members (probably on an annual basis). Again, there is only scant evidence before 1409, but this governance scheme corresponds with the general practice of religious fraternities at the time (Lauf 2004, p. 124).

In 1473, during the recovery of mining after the economic crisis of 1360-1400 (Bartels et al. 2007), a second mutual aid society was documented in Goslar, the Fraternity of St. Barbara. Its charter contains similar provisions as the one of St. Johannis. In contrast to the 1260 charter, the Fraternity of St. Barbara counts both miners and the mine owners ("Gewerkschaft der vier Schichten") as members and not only miners, which reflects the growing number of dependent mine workers in Goslar. Also, the city council of Goslar, at the time the effective owner and operator of the Rammelsberg mines, ruled in 1476 that the mine workers had to pay half a penny weekly into the brotherhood's fund ("Büchsenkasse"). This is the first time that Goslar's historical records document a compulsory financial contribution to the brotherhood's fund (Bartels 2012; Kraschewski 2012, pp. 302-304).

\section{The Turmoil After the Reformation: Dissolution of Religious Fraternities and the Public Alms Box (1527-1532)}

In the course of the Reformation in the sixteenth century, rulers and authorities in the Holy Roman Empire (of the German Nation) who adopted the Lutheran confession began

\footnotetext{
Footnote 4 (continued)
}

opportunities to achieve God's mercy. Cf. Frerich and Frey (1993, pp. $5-6)$. to dissolve many religious organizations, including monasteries that had operated poor houses and hospitals. When the poor started to migrate in droves into the towns for help, cities such as Augsburg in 1522 or Regensburg and Magdeburg in 1524 introduced poor laws to systematize the variegated and dispersed care for the poor. Although motivated by charity, cities also tried to reduce disincentives to work for the poor, thereby keeping foreign beggars at bay (Frerich and Frey 1993, pp. 7-8).

Lutheran Goslar dissolved the fraternities of the miners in 1529 (Bingener 2012, p. 17), appropriated the miners' fund and used it to create a public alms box dedicated to provide charity for the city's beggars and the poor (the "Gemeine Kasten", cf. Bingener 2009). Although sick and poor miners could resort to the alms box for help, the charity granted was much less generous than the aid received earlier through the abolished fraternities. The turmoil following the reformation deprived the miners of a centuries-old community-based system of mutual care, including the hospital of St. Johannis. Goslar had it put down during a military campaign against the Duke of Brunswick-Wolfenbuettel in 1527 (Bartels et al. 2007).

The alms box was poorly attuned to the miners' needs and soon met with their criticism. In 1532, Goslar's miners rallied in St. Mary's churchyard to discuss potential solutions and expressed their will "to establish and maintain a new regime" ("Ordnung") of mutual care to assist the crippled and sick (Bingener 2012, p. 22). These claims reflected the long-standing experience of the fraternities in determining, collecting, and safekeeping financial contributions, and in granting needed assistance. Each miner should pay half a penny per week into a new fund. When the miners' representatives discussed these proposals with the city council, many of whose members were mine owners, the council approved a miners' fund and provided a substitute hospital within the town walls. After a second gathering in 1532, the mine-owning councilmen granted additional subsidies to the miners' fund by way of allowing the miners to appropriate all the stone fragments that dropped out of transport wagons to the benefit of the miners' fund (Bingener 2012, p. 22). ${ }^{5}$

In 1536, the elected elders gave an account of the revenues and expenses of the fund during another miners' meeting (Kraschewski 1989, p. 289). The ensuing discussions led to further amendments to the fund's rules. Regarding costs, the miners discussed a proposal to reimburse medical bills for the treatment of injured miners. It was also decided to double each mine worker's contribution to the fund to one penny per week. Also, the mine workers collectively authorized the mine owners to refuse those miners in arrears the tallow needed to light the miner's lamp, which meant

\footnotetext{
${ }^{5}$ Cf., also, Dapprich (1979, p. 31) and Thielmann (1960, pp. 16-17).
} 
effectively barring those miners from work in the Rammelsberg mines. Miners who were non-compliant with the social fund's rules ran the risk of losing their jobs (Bingener 2012, p. 23).

\section{The Miners' Guild of Goslar ("Knappschaft"): The Mining Regulation of 1538}

The mining regulation of 1538 marks the provisional endpoint of political upheaval and turmoil following the Reformation. It met with the miners' demands, consistently expressed since 1529 , to establish an organization of mutual aid and care that compensated for the loss of the religious brotherhoods, including the social fund. The city council of Goslar established a regulatory framework for a new miners' guild - the "Knappschaft" - that included all miners working in the Rammelsberg mines. This regulation, the "Ordnunge und Regiment der Berchgesellen Anno 1538", is the first regulation to determine social benefits for a specific group of professionals in history. It incorporates the tried-and-tested rules established over centuries, including compulsory membership, membership fees, and sanctions for rule violations. In 1552, when the Duke of BrunswickWolffenbuettel became the single mine owner of the Rammelsberg and the Harz region, he granted the miners the same rights as the 1538 town regulation ("Riechenberger Vertrag", cf. Bingener 2012, pp. 24-27).

First, related to financial management, the regulation introduced a series of rules to avoid the embezzlement of the guild's funds. Every year, the miners elected a governance body, a board of elders, to collectively manage the guild's finances and benefits. The workers elected two elders from the group of managers, whereas the managers elected two representatives from the group of workers. Together, the four elders were supposed to ensure a just allocation of social benefits to the poor and sick miners, of which they had to give an account by the end of the year. During the annual meetings, the miners were required to refrain from any "discord, strife, or dispute." Miners who violated the peace rule were fined and banned from work. Although they were not members of the guild, the mine owners, represented by the bailiff ("Bergvogt"), had to supervise the financial report given by the elders in front of the miners during the annual meeting (Bingener 2012, pp. 24-26).

Second, related to social benefits, the regulation contained various forms of welfare benefits for miners due to mining accidents, including financial benefits, hospital care, the payment of medical bills and loans to individuals. The rules governing each type of social benefit varied and the elders had to apply them in every single case they examined. The most basic rule, however, was that of indirect reciprocity. Miners in need could receive financial assistance only if they had proven to have consistently paid their dues.
When back to work, miners who had received financial support, e.g., for medical bills, and insolvent miners who were granted a temporary loan from the guild's fund were required to donate to the needy in addition to repaying their loans. The elders also admitted sick and disabled miners to the hospital, typically until the next annual meeting. Hospital patients had to follow strict rules of behavior, and their possessions had to be donated to the poor in case of death (Bingener 2012, pp. 24-26).

Finally, the 1538 regulation also contains rules for right and good behavior for members of the miners' guild. The miners' guild law, in the spirit and tradition of the religious brotherhoods, required every miner to attend worship services every Sunday and to practice good manners both during service time and on other occasions (Bingener 2012, p. 26).

\section{Goslar's Mutual Aid Societies: The Logic of Pragmatic Experimentation with Institutional Solutions to Political-Economic Crises}

The chronology of mutual aid in Goslar's mining community between 1200 and 1552 reveals two structural elements. First, we witness the mining community experiment with new institutional solutions to social problems. When problems arise, the community develops possible explanations, tests solutions, and learns from experience. As circumstances change and implemented solutions lose their usefulness, we see a multitude of actors-miners, mine owners, bishop, city council—responding by reforming institutions to better meet the needs of the miners. Second, we observe institutional change in 'waves.' Radical institutional innovation after a crisis alternates with a period of relative stability and minor adaptation.

The sequential occurrence of these elements is well captured when we reinterpret Wicks and Freeman's (1998) idea of pragmatic experimentation within the broader framework of institutional change referred to as a "punctuated equilibrium" (Gersick 1991; Krasner 1984). Wicks and Freeman's (1998, pp. 124-130) notion of experimentation refers to the "search for novel and innovative approaches" of organizations "to help people lead better lives", while pragmatism points us toward the idea that experimentation provides the way to find the most "useful" alternatives for resolving social and moral problems. ${ }^{6}$ The punctuated-equilibrium model

\footnotetext{
${ }^{6}$ Wicks and Freeman (1998, pp. 130) write: "Pragmatists put as much emphasis on usefulness as they do on novelty, such that a concern with the practical must shape and channel the spirit of experimentation. Thus, different kinds of evidence and research, including empirical studies, can be helpful in grasping the implications of alternative ways of thinking and acting in the world, and serve as a useful source of evidence to complement other insights."
} 
of institutional change borrows from evolutionary theory (Mahoney and Thelen 2010, p. 7) and argues that a crisis or disruption, either caused from outside or inside the system, provides a window of opportunity for disruptive change in institutions and organizations. After that, equilibrium conditions allow for piecemeal changes and small adaptations within established institutions (Krasner 1984, pp. 241-243).

Reinterpreted within the punctuated-equilibrium model of institutional change, Goslar's medieval history of mutual aid can be understood as a history of institutional change in response to a series of crises that cause the mining community to innovate - or experiment pragmatically with (Wicks and Freeman 1998) —organizational and institutional solutions of mutual care. Pragmatic experimentation refers to the phase of disruptive institutional innovation after a political-economic crisis and the phase of minor adaptations to these institutions when the mining community improves its rules and rule enforcements. To capture this process, we spotlight the response to two major crises (Table 1), and we use concepts commonly employed in economic institutionalism: organizations as groups, institutions as rules of the game, and rule enforcement as monitoring, auditing and sanctioning (Dorobantu et al. 2017; Greif 2006; Hielscher et al. 2012; North 1990; North et al. 2009; Ostrom 2010; Pies et al. 2009).

\section{Crisis 1: Lack of Mutual Care in Mining Communities (ca. 1200)}

Miners faced new social challenges when they migrated to settle with their families in the medieval mining districts. In some sense, this is a disruptive crisis of mutual care. To see this, it is useful to compare the situation of full-time miners with other professions at the time. Mining in medieval stone quarries and coal mines was usually a part-time occupation of manorial tenants who were sent out for seasonal mining campaigns by their landlords, usually between sowing and harvest. In cases of injuries and illness, those miners could rely on the customary social institutions of the feudal manor, including the mutual assistance provided by the extended family and the care and support granted by the local lord. ${ }^{7}$ And so could the citizen of medieval towns. When cities started to grow in the eleventh century, fulltime artisans, mongers, and merchants who migrated to the burgeoning towns established crafts and merchants' guilds that developed a system of care in analogy to the manorial model of mutual support. For instance, by employing fellows and apprentices, a guild master integrated them as family members and provided professional guidance and training as well as shelter, food, and support in cases of illness (Kieser

\footnotetext{
${ }^{7}$ Personal correspondence with C. Bartels.
}

1989). Full-time miners, however, fell through the cracks of the existing framework of social care when mining expanded in the Early Middle Ages.

The miners in Goslar responded to this critical challenge by establishing a social organization dedicated to taking care of their sick, injured, indebted, and elderly miners, including their families and the invalid widows, which was later confirmed by the bishop's charter as a religious fraternity. ${ }^{8}$ This innovation is modeled from other forms of social organization at the time-fraternities and craft guilds (Lauf 2004). Their services reflect the miners' common interests of mutual care. The miners coordinated these services with a set of emerging institutions. Funding was based on a rule of regular contributions, and voluntary donations were encouraged by the bishop granting a generous indulgence package. Also, aid was conceived of as a type of loan covering additional costs for food and shelter, tied to the promise of repayment after recovery.

Rules were also set in place to determine the need of brothers; eligibility for aid was typically decided collectively or by the priest of the brotherhood, who also administered the hospital. Many of these rules were self-enforced by the miners and their brotherhood. But the bishop's charter and the "duty of operation" rule incorporated in the mining law also shows a considerable amount of rule enforcement by third parties that nurtured a vital self-interest in flourishing mining operations and prosperous and well-functioning social organizations. ${ }^{9}$

First, the 1260 charter reflects the need for a newly established organization to be integrated into a patron-client network, and thus being protected by a member of the ruling elite (North et al. 2009, pp. 18-20). However, it should not come as a surprise that the first documented mutual aid society among professionals took shape as a religious brotherhood, and received protection from an ecclesiastical authority. Already in the ninth century, the church had started to take care of the poor, the sick and the disabled in the poorhouses and hospitals of monasteries. The church's role was motivated by a scholastic notion of mercy and salvation and focused on providing shelter and food (cf. Frerich and Frey 1993, pp. 5-6).

Second, when the German lords attracted full-time miners to the thriving mining districts, they tied the above-described

\footnotetext{
${ }^{8}$ One cannot say how "immediate" the miners' response was; we lack evidence before the 1200s. It seems likely, however, that it took a considerable amount of time until the miners' organized in mutual aid societies (Lauff 2004).

${ }^{9}$ Economic institutionalism differentiates between two types of rule enforcement. Individuals can self-enforce rules by agreement, or they can take advantage of more powerful, hierarchically superior organizations that enforce these rules as third parties (Greif 2006; North et al. 2009, p. 16).
} 


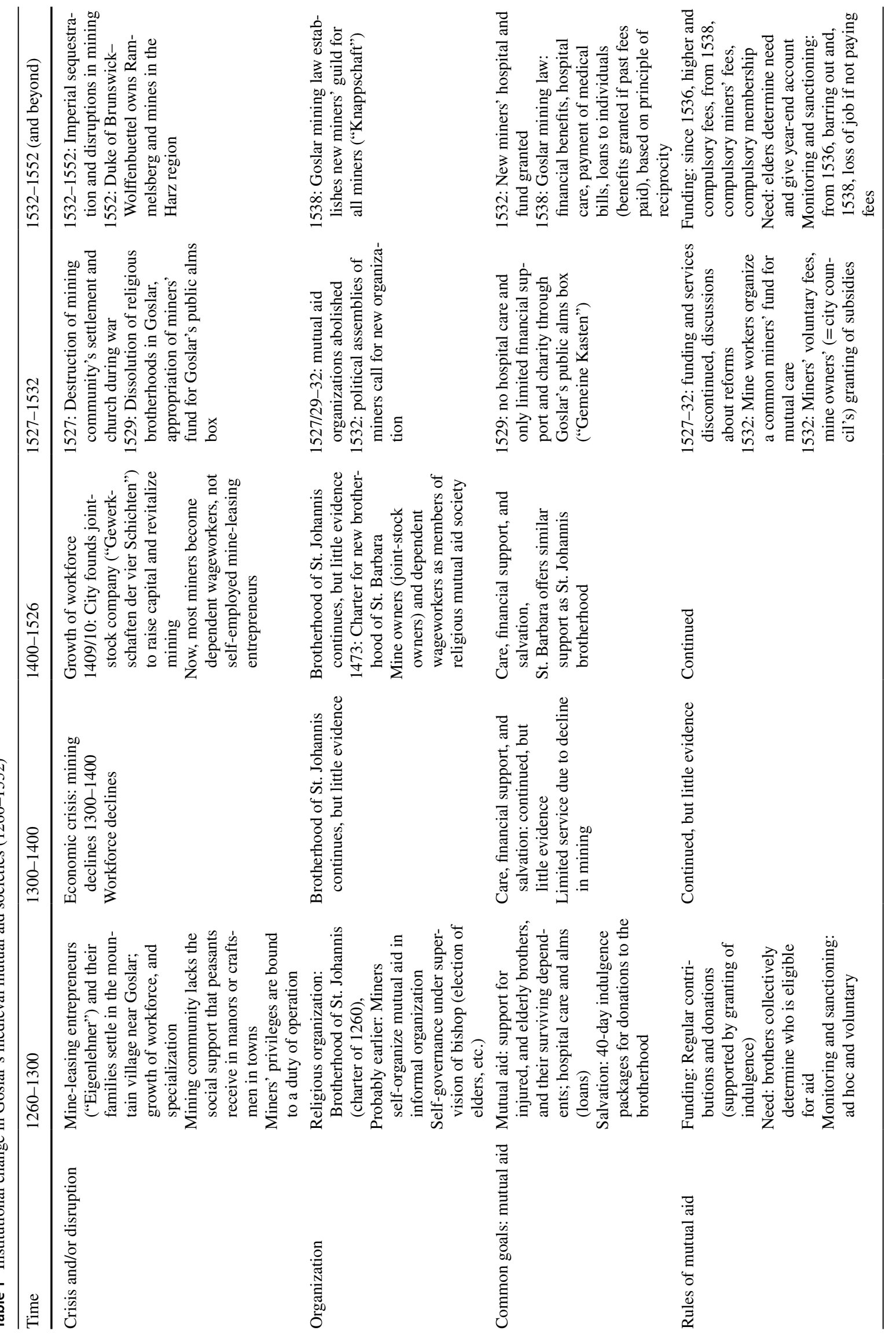




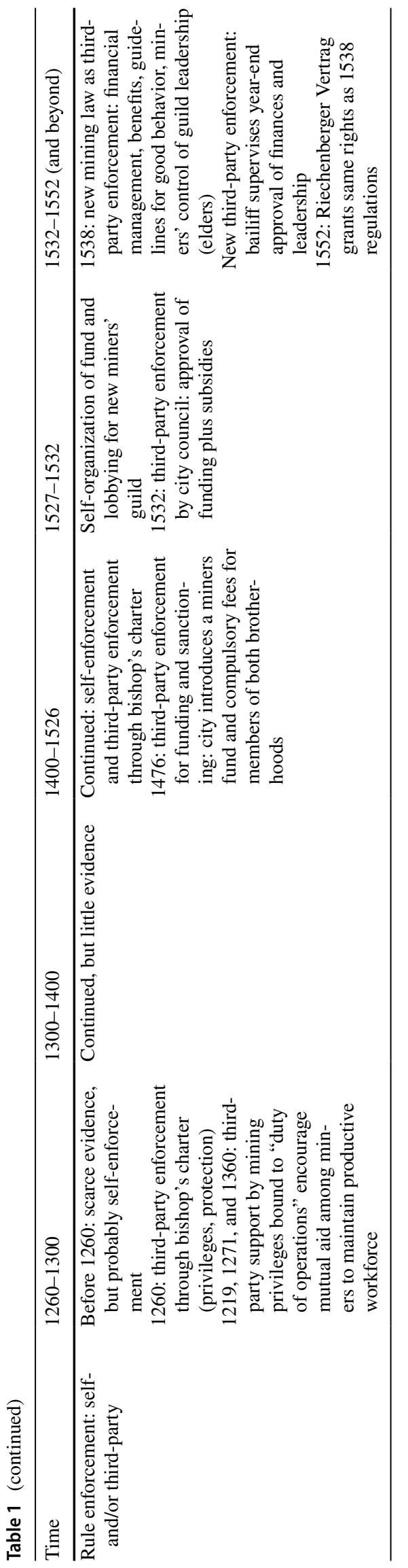

privileges to a "duty of operation" rule ("Betriebszwang"). Pits left unworked or abandoned for a certain period fell back to the owner for further leasing; miners incapable of working were excluded from the mining community and, therefore, lost their privileges (Bartels and Slotta 2012; Bartels et al. 2007). What was intended to keep the mines operating - and the stream of income flowing for the landowners and lords-also caused distress for the mining community and the lords. Since miners could not be easily replacedmining required specific knowledge and the knowledge was scarce in medieval times-taking care of the injured and sick miners was a call of prudence not only for the miners but also for the landowning lords to nurture and retain a productive workforce. Thus, the self-interests of the miners and the bishop coincided in supporting the brotherhoods of mutual aid. According to Bartels (personal communication), the diocese's churches, monasteries, and parishes were major clients of Rammelsberg copper and lead. Avoiding production bottlenecks of one of the regional church's largest supplier of precious metals was a prudent investment.

The development of both brotherhoods also underlines the need to adapt rules and institutions to altered circumstances and needs. The historical record suggests that funding of the first brotherhood, starting in 1260 , was exclusively based on voluntary contributions and donations; the 40-day indulgence package as a way to encourage wealthy members of the mining community to make larger donations and endowments, including estates and manors, is the only hard evidence we have. However, the compulsory fee of 1476 illustrates the difficulties of sustaining regular funding for mutual aid based on voluntary contributions. The interesting fact that the miners effectively lobbied for a city regulation suggests that the earlier system of voluntary donations and contributions was insufficient to secure the desired level of mutual aid for a larger and dependent workforce (Bingener 2012, p. 21). In 1476, it seems that the centralized ownership and management of the Rammelsberg mines - organized by the proto-capitalist joint-stock company (Gewerkschaft der vier Schichten)—allowed Goslar's city council to professionalize the rules of funding, including a common fund for all miners and compulsory contributions. What appears to be a very long time, however, was interrupted by almost a century of decline and a production halt between 1300 and 1400. The city's regulation of 1476 came into effect exactly when a second boom began at the Rammelsberg, and another brotherhood was documented in Goslar.

\section{Crisis 2: Lack of Mutual Care After the Reformation (ca. 1530)}

The decisions of the Goslar city council in the course of the Reformation-abolishment of religious fraternities, destruction of the church and the miners' hospital, and 
appropriation of the miners' mutual aid fund-plunged the community of miners into a new crisis. Again, the mining community was deprived of a cooperative system of mutual aid and had to resort to minor charity provided through the public alms box.

The miners' response to the distributive change after the Reformation until 1538 reiterates in miniature the trajectory of institutional change after the first crisis. Initially, the miners engaged in self-organization, establishing a new miners' fund, some services of mutual aid, and rules of voluntary funding that, two years later, were replaced by a rule of compulsory fees. Also, the miners flanked these efforts with political activism, in some ways resembling the lobbying of the 1470s, putting forward demands to establish a durable social organization of mutual aid that would re-install the services provided by the fraternities and the rule of compulsory contributions and sanctions in case of rule violations.

In 1538, when the city of Goslar issued a miners' guild regulation with detailed institutions, mutual care in mining entered a new stage with fully-fledged third-party enforcement. While retaining tried-and-tested rules and provisions, they also included rule innovations (a bailiff supervises the year-end approval of finances and leadership). All this suggests that these institutions of mutual aid imposed and enforced by third parties - in particular the rule of compulsory funding and the sanctioning of its violations-can be seen as a point of culmination of a long-standing history of experimentation with organizational and institutional solutions to a pressing social problem, including adaptation to intermittent changes.

\section{Goslar's Mutual Aid Societies in Context: The Mutual Aid Societies in Schwaz (Tyrol) and Elsewhere}

Historical research suggests that the social institutions of Goslar's mining community influenced comparable social organizations in other mining districts (Kraschewski 2012, pp. 204-306; Bartels and Klappauf 2012, p. 122). So, to the extent that social institutions differ from solutions in other mining districts, what other structural elements are different?

First, institutions of mutual aid seem to have existed in all larger mining communities but the organizational forms differed. For example, it is striking that religious fraternities are not documented in towns and settlements exclusively dedicated to mining-such as Altenberg (Siegerland, Westphalia), Biberach (Black Forest, Baden), or the Zschopautal (Ore Mountains, Saxony) (Lauff 2004). In single-purpose mining settlements such as these, social functions were performed by the mining town authorities. Larger, multi-purpose towns hosted a variety of crafts, trades, and merchants that formed their own fraternities for economic, social, cultural and political purposes (Kieser 1989). In these settings, there was a need to form fraternities not only for charity reasons but also to differentiate the miners from the status groups organized in other crafts and guilds (Lauf 2004, pp. 121-122).

Second, the structure of mine ownership seems to be associated with different types of rule enforcements-more decentralized self-enforcement and more centralized thirdparty enforcement. Examples include the early religious fraternities of miners in Freiberg (Saxony) of which only little data survived. In the thirteenth century, a silver rush prompted Goslarian miners to migrate to the mining districts in the Ore Mountains of Saxony and Bohemia, and Freiberg was founded as a town exclusively to host the incoming mining community. Freiberg grew and quickly became a multipurpose town with specialized crafts, trades and mining fraternities. ${ }^{10}$ But the miners faced a legal situation where mine ownership was in the hands of one political authority - the Duke of Saxony - not many as in Goslar (Bartels et al. 2007, pp. 76-101). The owner used his authority to centralize oversight, and the ducal mining judge exerted an authoritarian regime in the mining community-the elders, for example, were appointed by the Duke of Saxony not the miners. This strong third-party influence came with costs and benefits. In contrast to Goslar, for example, Freiberg's later historical records are rife not only with political tensions between the mining community and the ducal mining office but also with the mining office's efforts to improve funding rules and forestall the embezzlement funds at the hand of miners (Bingener 2012, pp. 45-51).

The institutional solutions in Schwaz (Tyrol), another important medieval mining district in Central Europe for which good data exist (cf. Bingener 2012, pp. 30-41), confirm the role of ownership structure in rule-enforcement and highlight the role of size in monitoring, auditing, and sanctioning rule implementation (cf. Table 2).

The silver rush in Schwaz (starting in 1420 with the rediscovery of silver and copper ore) echoes the crises in twelfth-century Goslar. When flocks of miners flooded the tiny market place of Schwaz in the fifteenth century, many of them from Goslar, the local Duke of Tyrol was quick to establish mining privileges (lended to a joint-stock company in 1427), a mining judge (1434), and the mining law (1449). The newly-formed mining community was equally swift in setting up the institutions of mutual care as they were known from Goslar, including a religious fraternity ("Gemeine Gesellschaft des Bergwerks zu Schwaz", 1443) and a fraternity house (a hospital called "Bruderhaus", founded soon after). Similarly, the hospital was dedicated

\footnotetext{
${ }^{10}$ Freiberg preserved a unique arrangement of hospital care from when it was a single-purpose town. The religious fraternities relinquished establishing their own hospital and, instead, funded a section in the town's hospital dedicated exclusively to miners (Bingener 2012, pp. 64-78).
} 


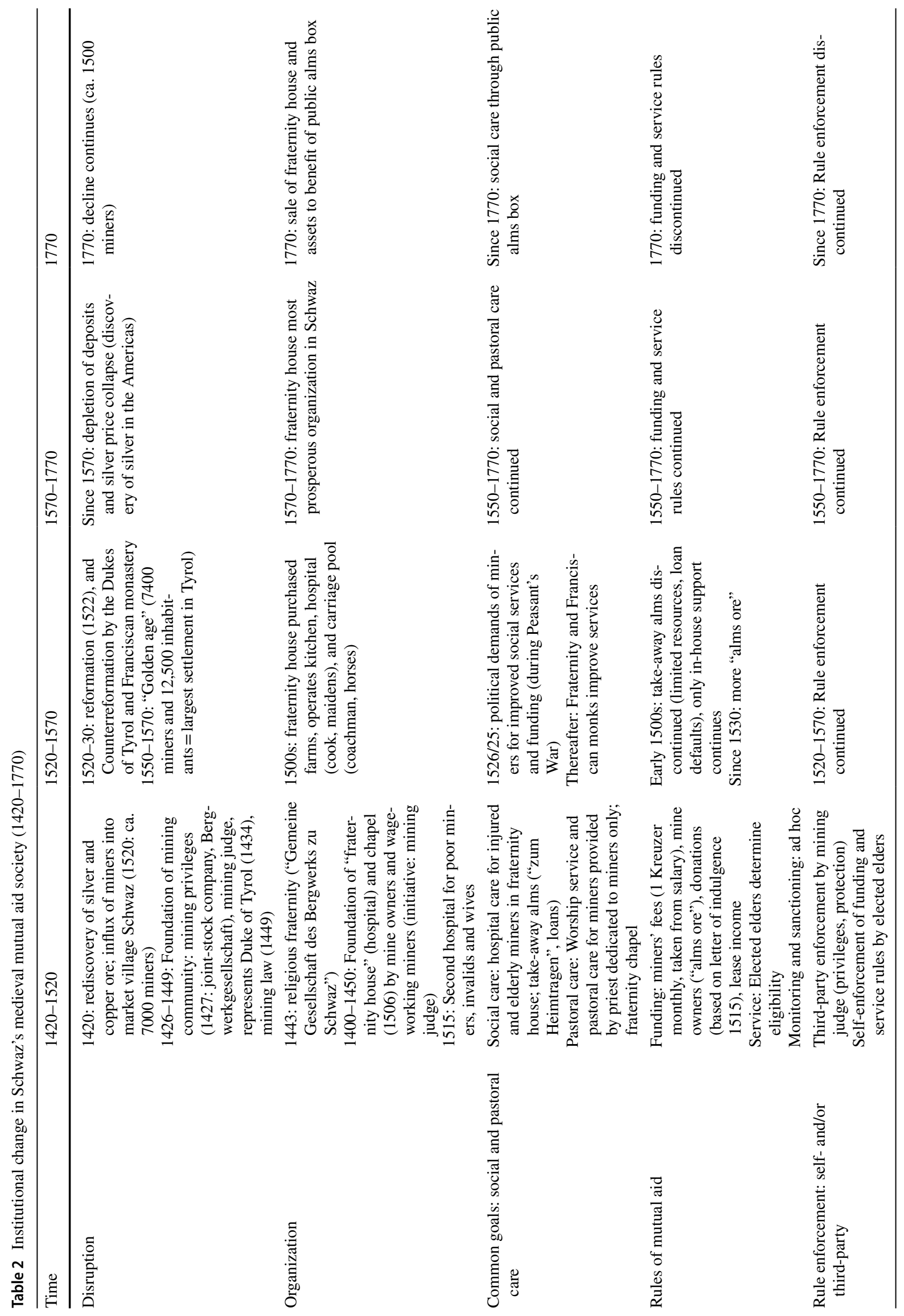


to the miners, but founded by the mine owners and the mine workers and not by self-employed mine-owning entrepreneurs, who had already disappeared from European mining by this time. Social and pastoral care was, similar to Goslar, funded by compulsory fees for miners, mine-owner contributions ("alms ore"), indulgence packages for donations, and lease income from mortgages the fraternity owned. The pronounced third-party enforcement of rules-joint-stock company and the ducal mining office in cooperation with selfgoverning miners-highlights that size sometimes requires central solutions. When medieval Schwaz flourished, it soon employed 7,500 miners and unskilled laborers (Hye 2005, pp. 84-87), whereas medieval Goslar never exceeded a workforce of 1000 (Bartels et al. 2007, p. 93).

The crisis of the sixteenth-century Reformation prompted the Duke of Tyrol to commission the Franciscan monks to increase their efforts to push back against the growing influence of Protestant ministers. This "Counterreformation" also included some important, mundane efforts to improve the funding of the miners' mutual aid organizations. The Franciscans and mine owners responded to the political demands of miners for better social services and increased the funding for the fraternity house in 1530, another interesting similarity to sixteenth century Goslar. During its golden age of mining, the fraternity grew in numbers and endowment. ${ }^{11}$ By this time, the fraternity also reformed the rules of mutual aid. Although the hospital still granted the generous service of take-away alms for injured miners, this practice was abandoned and replaced by in-house hospital support in the early 1500 s after miners continued to default on these loans. These rule reforms underline the increased need to monitor and audit social benefits when the numbers of miners increase in the community.

The depletion of copper deposits and the silver price collapse (after the discovery of large silver deposits in the Americas) marks the last crisis in Schwaz's mining trajectory, one which finds no analogy for the time line studied in Goslar (whose deposits were depleted only in the twentieth century). In Goslar, the still large mining workforce opposed the dissolution of fraternities in favor of the public alms box during the Reformation, whereas the diminished mining community of Catholic Schwaz embraced it in 1770 . Whereas in Schwaz, the remaining 1500 miners received social, health and old-age care from public town sources, sixteenth-century Goslar marks the foundation of the first secular mutual aid society for professional insurance that survived to this present day as a public national corporation

\footnotetext{
11 In the sixteenth century, the fraternity house in Schwaz became so affluent that it could purchase farms and employ horses, carts, and drivers for transportation, a cook to prepare food, servants and maidens to care for the sick, and, finally, a master to co-manage the hospital with two elected miners.
}

in Germany ("Knappschaft”), independent of Goslar's city government of course.

Finally, the histories of Schwaz and Freiberg emphasize the role of accumulated institutional know-how to sustain mutual aid. Migrating miners, who exported knowledge and institutional experience to other locations, seem to have allowed other mining communities to build upon tried-andtested practices, avoid mistakes, and accelerate the rate of innovation of institutional solutions that sustain mutual aid.

\section{Theorizing "Proto-CSR" Before the Industrial Revolution}

How can we make sense of the process of experimentation with institutional solutions to social problems, and how does it relate to modern CSR? We believe that these questions and some tentative answers are of interest to scholars devoted to the study of CSR.

\section{Theorizing the Process of Experimentation with Social Institutions}

What drives the process of experimentation with social institutions is a fascinating question. Here, we provide some food for thought to spark future theorizing.

\section{Collective Action in Clubs}

The challenge of mutual aid among the mining communities can be reconstructed as a problem of collective action, caused by a misalignment of private and public interests (Ostrom 2000): a miner benefits from the collectivelyprovided public good of mutual aid, but he is even better off omitting the payment of fees or the repayment of loans. Since free-riding - receiving public benefits without private costs-is attractive for every miner, institutions (the 'rules of the game') of mutual aid are required to fund benefits, and sustain hospital and pastoral care. In a sense, the mining communities are akin to clubs that enforce these funding rules through monitoring, audits and sanctions (cf., Prakash and Potoski 2007). This is indeed part of what we observe in the institutional history of the miner communities in Goslar and Schwaz. Paying fees and repaying loans are club standards under a permanent threat of erosion. To maintain these standards, new rules are consistently tested, including monitoring (e.g., in-house care instead of take-away alms in Schwaz), auditing (e.g., bookkeeping to detect embezzlement in Freiberg), and sanctioning (e.g., banning noncontributors from work in Goslar). 


\section{Enforcement Costs in Clubs}

The mining communities' ability to sustain mutual aid crucially depends the functionality of rules that address freeriding and organize collective action. First, when rules are dysfunctional-their incentive effects are poorly understood-the costs of self-enforcement in small clubs (small fraternities) are lower than those of larger clubs (entire communities). Mistakes affect fewer people when they occur in smaller groups, and defects can more easily be remedied by personal interaction. Funding rules are functional when their incentive effects on free-riding are well understood. In this case, the benefits of larger clubs exceed those of smaller ones. A functional rule can do more good when applied to many people instead of a few. What distinguishes the two situations of low and high rule functionality is the process of social innovation that accumulates institutional knowledge through experimentation. We conjecture that the cost functions of small and large clubs depend in different ways on the quantity and quality of accumulated enforcement know-how in monitoring, auditing, and sanctioning, the ability to pass this knowledge across generations, and the organizational capacity of potential clubs.

These two aspects - the problem of collective action and the enforcement costs of rules to overcome free-riding - contribute to explaining the observed differences in pragmatic experimentation across various mining communities. First, thirteenth-century Goslar is a hotbed for experimentation for good reason. Mine ownership is dispersed, and many early miners hold privileges and work their claims as independent entrepreneurs. This encourages small-club solutions that rely on informal, bottom-up community regulation of mutual aid. Second, a larger workforce (community size) and concentrated ownership (organizational capacity) favors top-down solutions in large clubs if functional rules adequate for large groups-formal monitoring, audits, and sanctions-can be designed based on accumulated institutional know-how. If this is a correct, the miners would have been primarily interested in functional rules that secure mutual aid benefits, with functionality provided either by more direct participation or less (cf. Hielscher et al. 2014). Circumstantial evidence supports this interpretation. First, in 1476, Goslar's miners lobbied for a centralized, less participatory city regulation to implement a compulsory funding scheme when most of them had become wageworkers of a larger mining company, mine ownership was more concentrated, and institutional know-how acquired. Second, concentrated mine ownership in fourteenth-century Freiberg and fifteenth-century Schwaz benefited from earlier experimentation in Goslar, so that mining communities found it easier to set up and accept functional institutions of mutual aid in large clubs dominated by political authorities.

\section{Proto-CSR: Antecedent Social Practices that Influenced Modern CSR}

How does all this pragmatic experimentation relate to modern CSR? Prima facie not much.

First, the feudalist system based on privileges, personal ties, and patron-client networks surely set the medieval guilds apart from what emerged during the ascent of capitalism in the eighteenth and nineteenth centuries. However, the birth of social insurance falls into a period often referred to as "medieval capitalism" (Greif 2006; North and Thomas 1973). Between 1100 and 1300, the craftsmen and merchants of the towns, the miners of the mining districts, and the Cistercian monasteries enjoyed unprecedented levels of economic freedom, including the freedom of movement, freedom from tariffs, self-governance, jurisdiction, and relatively low taxes (Baumol 1990).

Second, medieval capitalism was dominated by multipurpose organizations, for example, rural manors (North and Thomas 1973), urban crafts and the merchants' guilds (Kieser 1989) or mining communities (Bartels 2012). Resembling extended family structures, these organizations combined economic (production), social (care, assistance for co-workers, widows, and orphans), cultural (education), religious (salvation) and political (self-governance or rent creation) purposes (Kieser 1989, pp. 550-551). The capitalist firm, in contrast, is exclusively tied to the single purpose of creating value (Kieser 1989; Friedman 1962).

Still, the continuity between medieval and modern solutions is striking. First, there is an important topical continuity between the practice of mutual care in medieval mining communities and modern CSR that relates to occupational health, care, and old-age insurance among the poor (Berman 2014; Doane and Abasta-Vilaplana 2005). This was a central concern of the Goslar mining community's institutions of mutual care; it is also omnipresent in CSR practices as evidenced by the extensive health care, old-age and casualty provisions of the nineteenth-century industrial patriarchs in Germany, England, France, and the United States (Ashworth 1951; McCreary 1968). Health and retirement programs are also a cornerstone of modern CSR, as paid health care benefits by many US companies show (Matten and Moon 2008, p. 412). Finally, health care also features prominently in international CSR standards, including ISO 26000, Social Accountability 8000, the ILO Code of Practice on HIV/ AIDS and the World of Work, Responsible Care, and the Gender Equality Principles (cf. Leipziger 2016). ${ }^{12}$

\footnotetext{
12 ISO 26000 includes a section dedicated to "health and safety at work" in its CSR core subject "Labour practices" (ISO 20000, Clause 6.4). An application of ISO 26000 in the Middle East and Northern Africa (MENA) shows that health and safety is a priority for companies in the MENA region. CSR programs sometimes even entail a "health clinic to support the local community", as a hotel resort reports for Egypt (SR MENA 2016, p. 22).
} 
Second, a less well-known historical continuity relates to the nineteenth-century industrialists in the Ruhr and Rhine Valleys, Germany. Alfred Krupp, for example, is remembered as a pioneer of "industrial responsibility" (McCreary 1968) and among the first to have invented and developed a social welfare program, including an extensive health insurance plan, for an industrial workforce at a time of rapid development in one of Germany's centers of industrialization. Less well-known is the fact that the "idea for such programs was not original with Krupp", as McCreary (1968, p. 28) puts it, but that the eighteenth century regulations of the miners' guilds predated his programs and heavily influenced them. ${ }^{13}$ A similar continuity is historically documented for the introduction of a federal social welfare program in Germany by the end of the nineteenth century. The Bismarckian reform of the 1880s was influenced by the century-long history of social insurance in many industries, but particularly by Krupp's social welfare program of the nineteenth century (cf., e.g., McCreary 1968 or Bartels 2012). ${ }^{14}$ As a result, a line of continuity can be drawn starting in the Early Middle Ages, covering the Industrial Revolution and modern-day social legislation.

Third, there is continuity in moral aspirations. Many modern theoretical CSR notions emphasize the idea that pragmatic experimentation in organizations can "help people lead better lives" (Wicks and Freeman 1998: 124)_an idea that can be applied to CSR. Other approaches highlight the need for organizations to avoid doing harm and rectifying harm when it occurs (Campbell 2007). Both medieval social policy and contemporary CSR share a common focus on satisfying the basic human needs of those involved (in Goslar: the miners) or affected (in Goslar: the miners' widows and orphans) by capitalist or proto-capitalist production.

These continuities are the reason why we suggest the term proto-CSR to describe these practices which unfold in a process of pragmatic experimentation over centuries. Proto$C S R$ captures the idea of a pre-modern practice that influenced industrial and modern forms of CSR. ${ }^{15}$ It postulates

\footnotetext{
13 As McCreary (1968) remarks, these regulations, known as Knappschaftskassen in German, actually have antecedents in the 13th century.

14 McCreary (1968, pp. 29-30) puts it this way: "Although there is no direct evidence for the influence of Krupp on the Bismarckian national program (so often asserted by the company's official historians), there is sufficient circumstantial evidence to lend the assertion a degree of probability." The circumstantial evidence includes the close ties between the Krupp family and the Hohenzollern rulers, and between Alfred Krupp and Bismarck.

15 According to Merriam Webster's dictionary, proto means "first in time" or "beginning: giving rise to" (https://www.merriam-webst er.com/dictionary/proto). Both meanings capture our idea of protoCSR as a pre-modern antecedent that influenced, but is different from, modern forms of CSR.
}

that the relationship between these two practices, modern CSR and proto-CSR, features continuity and difference.

\section{Conclusion}

Our chronological narrative and the interpretation of medieval miners' guilds social policies as proto-CSR has implications for CSR scholarship, but also presents certain limitations, which can provide fodder for future research.

\section{Implications}

First, our study implies that a social practice of multiple-purpose economic organizations in the pre-modern era-such as medieval miners' guilds or crafts and trade guilds (cf., Kieser 1989)_qualifies as proto-CSR. Many practices studied in the history of CSR research fall into this category of proto-CSR (e.g., Good et al. 2018; Husted 2015), including the social activities of the British East India Company and the Hudson Bay Company (Wagner 2017). The concept of proto-CSR is consonant with the view that the social policies of late nineteenth-century UK industrialists (Parker 2014) or twentieth-century American corporations are examples of modern CSR (Carroll et al. 2012; Djelic and Etchanchu 2017).

Second, our chronological narrative differentiates and complements studies of the history of CSR practice focused on the twentieth or nineteenth centuries (Carroll et al. 2012; Djelic and Etchanchu 2017) and the eighteenth or seventeenth centuries (Husted 2015; Pettigrew and Smith 2017). Our study highlights the nature of proto-CSR as a co-evolution of ideas and institutions (cf. Pies et al. 2009). Of course, the first efforts of miners to create an organization of mutual care was built upon and promoted by the religious idea of Christian charity and fraternal love; it is no coincidence that the first mutual aid societies were modeled as Christian brotherhoods. Gradually refined and improved, the institutions of mutual aid appear to be rather robust when morphing from Christian brotherhoods into secular miners' guilds (in Goslar).

Third, and maybe the biggest implication, the history of Goslar's medieval mining community shows that much of proto-CSR is experimental, a search for novel solutions to social problems that involves a trial-and-error process and a sense of reasonable pragmatism (Wicks and Freeman 1998). From this, we conjecture that it might well be the case that, for example in the nineteenth century, business firms have started to experiment with institutions to address production-related social challenges until, at some point, a majority might have used the tried-and-tested instruments so broadly that governments find it easy to apply them universally. At this point, government implements regulation because firms 
find it in their interest to adapt their already existing practices to the statutory requirements embedded in law. We are not the first to propose this idea. For example, Reckendrees (2014) tells a similar story for old-age insurance and minimum wages. In the mid-nineteenth century, he argues, many early industrialists in the Western Prussian Rhine district (Aachen) collectively lobbied for minimum wage laws and old-age insurance long before Bismarck enacted national social reforms. At the time, in the 1860s, the Prussian government rejected the proposal, but many elements were taken up and incorporated into German national law in 1881.

We hypothesize that much of this innovative and pragmatic 'muddling through' and adjustment of institutions has somehow been lost to current research. Today, modern CSR largely confined to the straightjacket of reporting, management systems and other global guidelines. Standardization surely has its merits. Its weakness surfaces when CSR programs are translated into global emerging markets whose fluid institutional environment resemble more the premodern economy than modern political-economic contexts (North et al. 2009; Dorobantu et al. 2017). Often, when firms in developing markets adopt the global CSR agenda, they are implementing CSR programs word-for-word without changes. Often, this strategy fails to translate the same functionality (Jamali et al. 2017), because it lacks openness to learning and experimenting how these institutions can to be adjusted to fit indigenous cultural contexts and be effective. If proto-CSR would have been dealt with in a similar manner in medieval Goslar and other places, adopters could not have taken advantage of these experiences and modified them to their circumstances. This includes social welfare programs of industrialists and the social reforms of nineteenth-century legislators. We should consider that emerging markets might need the same freedom - and more Western tolerance for it-to develop effective institutions of CSR.

\section{Limitations}

Our selection of Goslar and Schwaz as the primary sites for research have some implications for the robustness and conclusiveness of the results obtained. The quality of data improves over the centuries documented, with the last period allowing for more robust results. At the origins of the miners' guilds organizations of mutual care in Goslar, Germany, i.e., in the twelfth century C.E., the data and documents are few and fragmented. Insights are mostly derived from archeological excavations. The data improves when it comes to thirteenth and fourteenth centuries, and are abundant in the fifteenth and sixteenth centuries, both in Goslar and Schwaz. In this period, we can rely on multiple historical documents collected in town archives (Goslar) and mining organizations (Schwaz).
Our historical narrative, therefore, triangulates the available data with that mutual aid societies in other Central European mining districts, in particular, with the miners' guild in Schwaz, for which more evidence exists. This approach allows broader insights into the institutions of mutual social assistance in the general context of medieval mining (Stutz and Sachs 2018). Nevertheless, this focus on a particular region, although illustrative, is not entirely generalizable. Other mining regions have not shown such institutional creativity, hence further comparative and historical research would be vital in order to understand under what conditions pragmatic experimentation flourishes or not.

In addition to the specific region, we have limited our focus to a specific set of proto-CSR practices related to mining and social insurance. Certainly, further research needs to be developed related to other aspects of CSR, such as environmental responsibility. Interestingly, the mining industry also gave birth to the practice of sustainable forestry (Carlowitz 1713). The links between early forms of environmental responsibility and current environmental practice may help to consolidate the ideas developed in this paper about proto-CSR and experimental pragmatism.

In summary, we have argued that scholarship interested in the historical antecedents of modern CSR should focus their attention also on the pre-modern era. Looking over several centuries, our chronological narrative highlights the patterns of pragmatic experimentation and co-evolution which can easily be missed when using a fine-grained analysis. However, we are acutely aware that our approach is also susceptible to misunderstandings. We thus conclude in the hope that future studies will be able to identify and correct potential misinterpretations stemming from the method used here.

Funding This study was funded by the Fritz Thyssen Foundation, Germany (Az. 50.16.0.002WW).

\section{Compliance with Ethical Standards}

Conflicts of interest Stefan Hielscher declares that he has no conflict of interest. Bryan W. Husted declares that he has no conflict of interest.

Open Access This article is distributed under the terms of the Creative Commons Attribution 4.0 International License (http://creativeco mmons.org/licenses/by/4.0/), which permits unrestricted use, distribution, and reproduction in any medium, provided you give appropriate credit to the original author(s) and the source, provide a link to the Creative Commons license, and indicate if changes were made.

\section{References}

Ashworth, W. (1951). British industrial villages in the nineteenth century. The Economic History Review, 3(3), 378-387. 
Bartels, C. (2012)....höchst verpönte Selbst-Hülfe... Zur Entstehung und Entwicklung der Sozialversicherung in Bergbau, Seefahrt und Eisenbahnwesen. Bochum: Deutsches Bergbaumuseum.

Bartels, C., Fessner, M., Klappauf, L., \& Linke, F. A. (2007). Kupfer, Blei und Silber aus dem Goslarer Rammelsberg von den Anfängen bis 1620 (Vol. 8, Montanregion Harz). Bochum: Deutsches Bergbaumuseum.

Bartels, C., \& Klappauf, L. (2012). Das Mittelalter. Der Aufschwung des Bergbaus unter den karolingischen und ottonischen Herrschern, die mittelalterliche Blüte und der Abschwung bis zur Mitte des 14. Jahrhunderts. In C. Bartels, \& R. Slotta (Eds.), Der alteuropäische Bergbau. Von den Anfängen bis zur Mitte des 18. Jahrhunderts (Vol. 18, pp. 111-248). Münster: Aschendorff.

Bartels, C., \& Slotta, R. (2012). Geschichte des deutschen Bergbaus, Band 1: Der alteuropäische Bergbau. Von den Anfängen bis zur Mitte des 18. Jahrhunderts. Münster: Aschendorff.

Baumol, W. J. (1990). Entrepreneurship: productive, unproductive, and destructive. Journal of Political Economy, 98(5), 893-921.

Berman, J. 2014. Unlike Walmart, Costco has no plans to cut employee health benefits. Huffington Post. Retrieved August 15, 2019, from https://www.huffpost.com/entry/costco-health-benefits_n_59535 26.

Bingener, A. (2009). Armenkasten oder Knappschaftsbüchse-der Kampf der Goslarer Bergknappen um eine eigene soziale Absicherung. Der Anschnitt, 61(5-6), 294-301.

Bingener, A. (2012). Die Geschichte der Knappschaft-eine Spurensuche von 1260 bis 2005. In C. Bartels (Ed.),...höchst verpönte Selbst-Hülfe...Zur Entstehung und Entwicklung der Sozialversicherung in Bergbau, Seefahrt und Eisenbahnwesen (pp. 13-200). Bochum: Deutsches Bergbaumuseum.

Bingener, A., Bartels, C., \& Fessner, M. (2012). Die grosse Zeit des Silbers. Der Bergbau im deutschsprachigen Raum von der Mitte des 15. bis zum Endes des Jahrhunderts. In C. Bartels, \& R. Slotta (Eds.), Der alteuropäische Bergbau. Von den Anfängen bis zur Mitte des 18. Jahrhunderts (Vol. 1, pp. 317-452). Münster: Aschendorff.

Campbell, J. L. (2007). Why would corporations behave in socially responsible ways? An institutional theory of corporate social responsibility. Academy of Management Review, 32(3), 946-967.

Carlowitz, H. C. V. (1713). Sylvicultura oeconomica: haußwirthliche Nachricht und Naturmäßige Anweisung zur Wilden Baum-Zucht. Remagen-Oberwinter 2009: Verlag Kessel.

Carroll, A. B., Lipartito, K. J., Post, J. E., \& Werhane, P. H. (2012). Corporate responsibility: The American experience. Cambridge: Cambridge University Press.

Ciulla, J. B. (2011). Is business ethics getting better? A historical perspective. Business Ethics Quarterly, 21(2), 335-343.

Clark, P., \& Rowlinson, M. (2004). The treatment of history in organisation studies: Towards an 'historic turn'? Business History, 46(3), 331-352.

Crane, A., Henriques, I., Husted, B., \& Matten, D. (2015). Defining the scope of Business \& Society. Business \& Society, 54(4), 427-434.

Czarniawska, B. (2004). Narratives in social science research. London: Sage.

Dapprich, G. (1979). Geschichtliche Entwicklung der Knappschaft (pp. 19-54). Bochum: 10 Jahre Bundesknappschaft.

Djelic, M.-L., \& Etchanchu, H. (2017). Contextualizing corporate political responsibilities: Neoliberal CSR in historical perspective. Journal of Business Ethics, 142(4), 641-661.

Doane, Deborah, \& Abasta-Vilaplana, Naomi. (2005). The myth of CSR. Stanford Social Innovation Review, 3(3), 22-29.

Dorobantu, S., Kaul, A., \& Zelner, B. (2017). Nonmarket strategy research through the lens of new institutional economics: An integrative review and future directions. Strategic Management Journal, 38(1), 114-140.
Etchanchu, H., \& Djelic, M.-L. (2018). Old wine in new bottles? Parentalism, power, and its legitimacy in business-society Relations. Journal of Business Ethics. https://doi.org/10.5465/AMBPP .2018.61.

Frerich, J., \& Frey, M. (1993). Handbuch der Geschichte der Sozialpolitik in Deutschland, Vol. 1: Von der vorindustriellen Zeit bis zum Ende des Dritten Reichs. München: Wien: R. Oldenburg.

Friedman, M. (1962). Capitalism and Freedom. Chicago: University of Chicago Press.

Gersick, C. J. G. (1991). Revolutionary change theories: A multilevel exploration of the punctuated equilibrium paradigm. Academy of Management Review, 16(1), 10-36.

Good, J., Vargas Montes, P., Husted, B. W., \& López de Mariscal, B. (2018). From Manhattan to Tenochtitlán: identifying ethical commercial norms. Journal of Management History, 24(4), 435-456.

Greif, A. (2006). Institutions and the path to the modern economy: Lessons from medieval trade. Cambridge: Cambridge University Press.

Hay, R. (1977). Employers and social policy in Britain: the evolution of welfare legislation, 1905-14. Social History, 2(4), 435-455.

Hielscher, S. (2011). Morality as a factor of production: Moral commitments as strategic risk management. In P. Koslowski (Ed.), Corporate citizenship and new governance The political role of corporations (pp. 117-132). Dordrecht: Springer.

Hielscher, S., Beckmann, M., \& Pies, I. (2014). Participation versus consent: Should corporations be run according to democratic principles? Business Ethics Quarterly, 24(4), 533-563.

Hielscher, S., Pies, I., \& Valentinov, V. (2012). How to foster social progress: An ordonomic perspective on progressive institutional change. Journal of Economic Issues, 46(3), 779-797.

Husted, B. W. (2015). Corporate social responsibility practice from 1800-1914: Past initiatives and current debates. Business Ethics Quarterly, 25(1), 125-141.

Hye, F.-H. v. (2005). Stadt und Bergbau in Tirol mit besonderer Berücksichtigung der Städte Hall und Schwaz. In T. Cernajsek, C. Hauser, \& W. Vetters (Eds.), Berichte der Geologischen Bundesanstalt (Vol. 65, pp. 81-89). Wien, Schwaz: Geologische Bundesanstalt, Austria.

Jamali, D., Lund-Thomsen, P., \& Khara, N. (2017). CSR institutionalized myths in developing countries: An imminent threat of selective decoupling. Business \& Society, 56(3), 454-486.

Kastl, J., \& Moore, L. (2010). Wily welfare capitalist: Werner von Siemens and the pension plan. Cliometrica, 4(3), 321-348.

Kieser, A. (1989). Organizational, institutional, and societal evolution: Medieval craft guilds and the genesis of formal organizations. Administrative Science Quarterly, 34, 540-564.

Kraschewski, H.-J. (1989). Zur Arbeitsverfassung des Goslaer Bergbaus am Rammelsberg im 15. und 16. Jahrhundert. In K.-H. Ludwig, \& P. Sika (Eds.), Bergbau und Arbeitsrecht. Die Arbeitsverfassung im europäischen Bergbau des Mittelalters und der frühen Neuzeit (pp. 275-304). Wien: VWGÖ.

Kraschewski, H.-J. (2012). Das Spätmittelalter: Zeit des Umbruchs. In C. Bartels, \& R. Slotta (Eds.), Der alteuropäische Berbau. Von den Anfängen bis zur Mitte des 18. Jahrhunderts (Vol. 1, pp. 249-316). Münster: Aschendorff.

Krasner, S. (1984). Approaches to the state: Alternative conceptions and historical dynamics. Comparative politics, 16(2), 223-246.

Lauf, U. (2004). Die Goslarer Bruderschaft der Bergleute von 1260: Eine Annäherung. Harz-Zeitschrift, 54(55), 115-132.

Leipziger, D. (2016). The corporate responsibility code book (3rd ed.). Sheffield: Greenleaf Publisher Ltd.

Luhmann, N. (1980). Gesellschaftliche Struktur und semantische Tradition. Gesellschaftsstruktur und Semantik: Studien zur Wissenssoziologie der modernen Gesellschaft, 1, 9-71. 
Lynch, M. (2002). Mining in World History. London: Reaktion Books Ltd.

Mahoney, J., \& Thelen, K. (2010). A theory of gradual institutional change. Explaining institutional change: Ambiguity, agency, and power (pp. 1-37). Cambridge: Cambridge University Press.

Matten, D., \& Moon, J. (2008). "Implicit" and "explicit" CSR: A conceptual framework for a comparative understanding of corporate social responsibility. Academy of Management Review, 33(2), 404-424.

McCreary, E. C. (1968). Social welfare and business: The Krupp Welfare Program, 1860-1914. The Business History Review, 42(1), 24-49.

Morgan, K. O. (1996). Lloyd George and Germany. The Historical Journal, 39(3), 755-766.

North, D. C. (1990). Institutions, institutional change, and economic performance (The Political economy of institutions and decisions). Cambridge, New York: Cambridge University Press.

North, D. C., \& Thomas, R. P. (1973). The rise of the Western world. A new economic history. Cambridge Eng.: University Press.

North, D. C., Wallis, J. J., \& Weingast, B. R. (2009). Violence and social orders. A conceptual framework for interpreting recorded human history. Cambridge: Cambridge University Press.

Ostrom, E. (2000). Collective action and the evolution of social norms. Journal of Economic Perspectives, 14(3), 137-158.

Ostrom, E. (2010). Beyond markets and states: polycentric governance of complex economic systems. American Economic Review, 100(3), 641-672.

Parker, L. D. (2014). Corporate social accountability through action: Contemporary insights from British industrial pioneers. Accounting, Organizations and Society, 39(8), 632-659.

Pettigrew, W. A., \& Brock, A. L. (2017). Leadership Leadership and the Social Agendas of the Seventeenth-Century English Trading Corporation. In A History of Socially Responsible Business, $c$. 1600-1950 (pp. 33-63). Cham, Switzerland: Palgrave Macmillan.

Pettigrew, W. A., \& Smith, D. C. (2017). A history of socially responsible business, c. 1600-1950. Cham: Palgrave Macmillan.

Pies, I., Hielscher, S., \& Beckmann, M. (2009). Moral commitments and the societal role of business: An ordonomic approach to corporate citizenship. Business Ethics Quarterly, 19(3), 375-401.
Pollard, S. (1964). The factory village in the industrial revolution. The English Historical Review. https://doi.org/10.1093/ehr/lxxix.cccxi i.513.

Prakash, A., \& Potoski, M. (2007). Collective action through voluntary environmental programs: A club theory perspective. Policy Studies Journal, 35(4), 773-792.

Reckendrees, A. (2014). Why did early industrial capitalists suggest minimum wages and social insurance? MPRA Paper No. 55520. Retrieved from http://mpra.ub.uni-muenchen.de/55520/.

Schrempf-Stirling, J., Palazzo, G., \& Phillips, R. A. (2016). Historic corporate social responsibility. Academy of Management Review, 41(4), 700-719.

SR MENA (2016). Benefits in applying ISO 26000. Selected case studies as a result of the SR MENA Project. Geneva: International Organization for Standardization (ISO.org).

Stöllner, T. (2012). Der vor- und frühgeschichtliche Bergbau im Mittelalter bis zur Zeit der Merowinger. In C. Bartels, \& R. Slotta (Eds.), Der alteuropäische Bergbau. Von den Anfängen bis zur Mitte des 18. Jahrhunderts (Vol. 1, pp. 25-110). Münster: Aschendorff.

Stutz, C., \& Sachs, S. (2018). Facing the normative challenges: The potential of reflexive historical research. Business \& Society, 57(1), 98-130.

Thielmann, H. (1960). Die Geschichte der Knappschaftsversicherung. Bad Godesberg.

Wagner, M. (2017). Profit and surety: The British chartered trading companies and the state. In A History of Socially Responsible Business, c. 1600-1950 (pp. 95-116). Cham: Palgrave Macmillan.

Wicks, A. C., \& Freeman, R. E. (1998). Organization studies and the new pragmatism: Positivism, anti-positivism, and the search for ethics. Organization Science, 9(2), 123-140.

Publisher's Note Springer Nature remains neutral with regard to jurisdictional claims in published maps and institutional affiliations. 